\title{
Concomitant Medication Category
}

National Cancer Institute

\section{Source}

National Cancer Institute. Concomitant Medication Category. NCI Thesaurus. Code C83218.

A classification of concomitant medication data. 